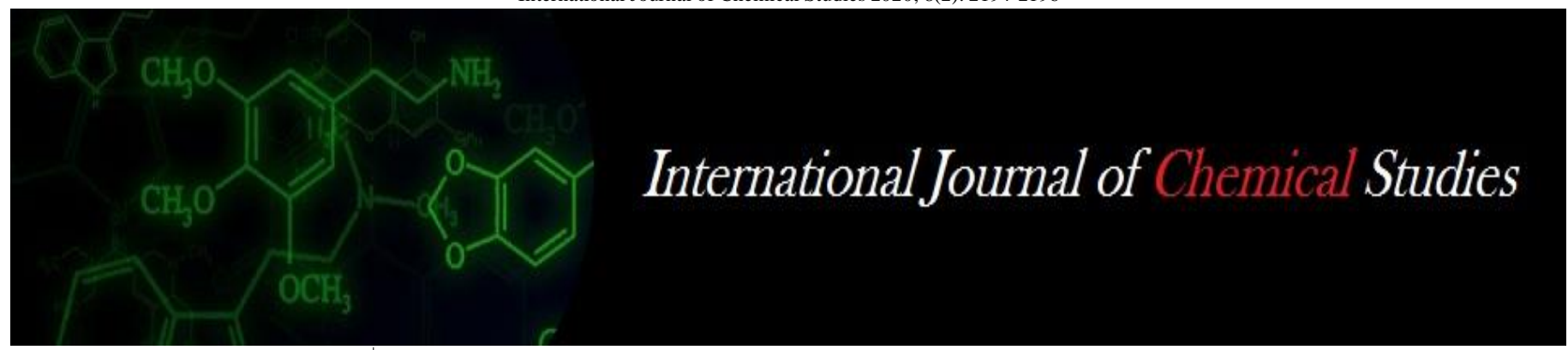

P-ISSN: 2349-8528

E-ISSN: 2321-4902

www.chemijournal.com

IJCS 2020; 8(2): 2194-2196

(C) 2020 IJCS

Received: 18-01-2020

Accepted: 20-02-2020

AA Patade

Dr. B. S. Konkan Krishi

Vidyapeeth, Dapoli, Dist.

Ratnagiri, Maharashtra, India

KV Malshe

Dr. B. S. Konkan Krishi

Vidyapeeth, Dapoli, Dist.

Ratnagiri, Maharashtra, India

UB Pethe

Dr. B. S. Konkan Krishi

Vidyapeeth, Dapoli, Dist.

Ratnagiri, Maharashtra, India

VV Sagvekar

Dr. B. S. Konkan Krishi

Vidyapeeth, Dapoli, Dist.

Ratnagiri, Maharashtra, India

Corresponding Author:

KV Malshe

Dr. B. S. Konkan Krishi

Vidyapeeth, Dapoli, Dist.

Ratnagiri, Maharashtra, India

\section{Influence of pinching on flower characters in different varieties of marigold (Tagetes spp)}

\author{
AA Patade, KV Malshe, UB Pethe and VV Sagvekar
}

DOI: https://doi.org/10.22271/chemi.2020.v8.i2ag.9077

\begin{abstract}
The field trial was conducted during Rabi season of the year 2017-18 to study the influence of different levels of pinching (Control-No pinching, Pinching after 3 weeks of transplanting, Pinching after 5 weeks of transplanting and Double pinching -Pinching after 3 and 5 weeks of transplanting) on flower characters in different marigold varieties (Pusa Basanti Gainda, Pusa Arpita and Yellow 09). Among the varieties, the flower diameter $(5.94 \mathrm{~cm})$, fresh and dry weight of flower $(6.91 \mathrm{~g}$ and $1.73 \mathrm{~g}$, respectively) and vase life of flower (7.02 days) was found to be significantly superior in Hybrid Yellow 09. The maximum flower diameter $(5.48 \mathrm{~cm})$ fresh and dry weight of flower $(6.02 \mathrm{~g}$ and $1.83 \mathrm{~g}$, respectively) and vase life of flower (6.69 days) was significantly superior in pinching at 5 weeks after transplanting. In interaction, the fresh and dry weight of flower, vase life was improved in double pinching in Yellow 09.
\end{abstract}

Keywords: Marigold, variety, pinching, flower diameter, flower weight, vase life

\section{Introduction}

The flowers are God given gift of Nature. They form the soul of garden and convey message of Nature to man. India has a long tradition of floriculture. It has recognized as a lucrative business since it has higher potential per unit area than most of the field crops even horticultural crops both for domestic market and export. Among the different loose flowers, marigold is one of the most commercial flower extensively used for making garlands for religious and social functions. It has wide adaptability with easy cultivation practices. Several varieties of marigold have been developed through crop improvement and the performances of these vartieties vary at different location.

As the varieties have different growing pattern hence their response towards pinching may vary accordingly. There is a great scope for increasing area under Marigold in Konkan region as soil and climatic conditions are well suited for its cultivation. Special horticultural practices are important for optimum growth, high yield and good quality flowers. Pinching is one of the most suitable practices for successful cultivation of cut flowers. The flower characters may also vary due to growing particular variety in any region and also due to manipulation in the cultural practices. The flower characters flower weight, size, vase life, etc. are the qualitative as well as quantitative parameters and associated to market response. Hence, the present investigation entitled "Influence of different pinching treatments on flower characters in different varieties of marigold (Tagetes spp)".

\section{Material and methods}

The field trial was carried out during Rabi season of the year 2017-18 at Department of Horticulture, College of Agriculture, Dapoli, Dist. Ratnagiri, (Maharashtra state). The trial was laid out in the factorial randomized block design with three replications. The treatment combinations comprised three varieties as viz; Pusa Basanti Gainda, Pusa Arpita and Yellow 09 with four levels of pinching (Control-No pinching, Pinching after 3 weeks of transplanting, Pinching after 5 weeks of transplanting and Double pinching -Pinching after 3 and 5 weeks of transplanting). The flat beds of $2.7 \times 1.8 \mathrm{~m}$ size were prepared and the seedlings were transplanted at the spacing of $45 \times 45 \mathrm{~cm}$. The recommended cultural practices were followed for raising the crop. The pinching treatments were given to each plot at prescribed time. The observations on flower characters (Flower diameter, fresh and dry weight of individual flower and vase life) were recorded. The data were analyzed by standard method of analysis of 
variance described by Panse and Sukhatme (1995) ${ }^{[6]}$.

\section{Results and discussion}

The data regarding flower diameter presented in Table 1 revealed that individually varieties and pinching treatments showed significant variation among themselves but their interaction did not influence significantly. Among the varieties, flowers of Yellow 09 variety $\left(\mathrm{V}_{3}\right)$ had significantly maximum diameter $(5.94 \mathrm{~cm})$ and lowest $(4.10 \mathrm{~cm})$ Pusa Arpita $\left(\mathrm{V}_{2}\right)$. The pinching had a remarkable effect on increasing size of flowers which ultimately increased the flower diameter. Among the pinching treatments, maximum flower diameter $(5.48 \mathrm{~cm})$ was recorded in $\mathrm{P}_{3}$ i.e. pinching after 5 weeks of transplanting. It was followed by $\mathrm{P}_{3}$ and $\mathrm{P}_{2}$. The shortest flower diameter $(4.27 \mathrm{~cm})$ was measured in $\mathrm{P}_{1}$ i.e. control. In interaction, numerically maximum flower diameter was in $\mathrm{V}_{3} \mathrm{P}_{3}$ and minimum flower diameter was in $\mathrm{V}_{2} \mathrm{P}_{1}$. Variation in the flower diameter might be due to the genetic makeup of the varieties and their interaction with prevailing genotype and environment. Similar results were observed by Narsude et al., (2010) [5], Deepa et al., (2016) ${ }^{[2]}$ in marigold. The increase in flower diameter under pinching treatment might be due to physiological effect of pinching practice which can be helpful to gain of extra energy. Similar results were observed by Mohanty et al., (2015) ${ }^{[4]}$ and Asif Khan et al, (2018) ${ }^{[1]}$ in marigold.

The data regarding weight of flower (fresh and dry) are presented in Table 2. It is apparent from the data that fresh weight of individual flower was significantly affected by the different varieties, pinching and their combined effects. Among the varieties, the significantly maximum fresh weight of flower $(6.91 \mathrm{~g})$ was recorded in variety Yellow $09\left(\mathrm{~V}_{3}\right)$ and minimum fresh weight (4.16 g) was recorded in Pusa Arpita $\left(V_{2}\right)$. The significantly highest fresh weight of flower $(6.02 \mathrm{~g})$ was in $\mathrm{P}_{3}$ i.e. pinching after 5 weeks of transplanting and it was followed by $\mathrm{P}_{4}$ and $\mathrm{P}_{2}$. The minimum fresh weight (4.98 g) was recorded in $P_{1}$ i.e. control no pinching. The interaction effect between varieties and pinching treatments was found significant and maximum fresh weight of flower (7.54 g) was recorded in Yellow 09 variety with pinching after 5 weeks of transplanting in $\left(\mathrm{V}_{3} \mathrm{P}_{3}\right)$. It was followed by $\mathrm{V}_{3} \mathrm{P}_{2}, \mathrm{~V}_{3} \mathrm{P}_{4}$ and $\mathrm{V}_{3} \mathrm{P}_{1}$. The lowest fresh weight $(3.37 \mathrm{~g})$ was recorded in $\mathrm{V}_{2} \mathrm{P}_{1}$ i.e. no pinching in Pusa Arpita.

The variation in weight of flower might be due to the variation in size, length of flower and number of petals flower. The results are in close agreement with the findings of Narsude et al., (2010) ${ }^{[5]}$, Deepa et al., (2016) ${ }^{[2]}$ in marigold. As the flower size in pinching treatments improved which ultimately complimentary for increase in flower weight. The beneficial effect of pinching on flower weight was earlier reported by Rathore (2007) ${ }^{[8]}$.

The significantly maximum weight of dry flower $(1.73 \mathrm{~g})$ was recorded in Yellow $09\left(\mathrm{~V}_{3}\right)$ and lowest $(1.24 \mathrm{~g})$ was in Pusa Arpita $\left(\mathrm{V}_{2}\right)$. The weight of dry flower was differed significantly due to pinching treatments and maximum weight of dry flower $\left(1.83 \mathrm{~g}\right.$ ) was recorded in $\mathrm{P}_{3}$ i.e. pinching after 5 weeks of transplanting. It was followed by $\mathrm{P}_{2}$ and $\mathrm{P}_{3}$. The lowest weight of flower (dry) was in $\mathrm{P}_{1}$ i.e. control no pinching $(1.19 \mathrm{~g})$. In interaction between varieties and pinching, significantly maximum weight of dry flower (1.98 g) was recorded in $\mathrm{V}_{3} \mathrm{P}_{3}$ and it was at par with $\mathrm{V}_{1} \mathrm{P}_{3}$ and $\mathrm{V}_{3} \mathrm{P}_{2}$ combinations. However, the minimum dry flower weight $(0.98 \mathrm{~g})$ was in $\mathrm{V}_{2} \mathrm{P}_{1}$ (Table 2). The difference in weight of the dry flower might be due to variation in moisture loss from the fresh flower and pigment content in flowers. This character determines the vase life of the flowers and varied among the varieties. Beside this, the variation in dry weight of flower was noticed that could be associated with variation in relative fresh weight of the same flowers. The difference in dry weight of flower might be due to inherent characters of the individual genotypes. The findings of the present investigation confirm well with results reported by Singh and Singh (2006) ${ }^{[9]}$.

The vase life of the cut flower is quality parameters from market point of view. Higher vase life is essential for reducing the post-harvest losses. And the vase life of the flower is governed by environmental conditions and adopted cultural practices.

The data on vase life of marigold flower are presented in Table 3 revealed that the vase life of the flowers was significantly influenced by different pinching treatments in different varieties. Among the varieties, significantly highest vase life (7.02 days) was achieved in Yellow $09\left(\mathrm{~V}_{3}\right)$ followed by $\mathrm{V}_{1}$. The lowest vase life (4.71 days) was in Pusa Arpita $\left(\mathrm{V}_{2}\right)$. In pinching treatments maximum vase life (6.69 days) was in $\mathrm{P}_{4}$ treatment (double pinching) followed by $\mathrm{P}_{3}$ and $\mathrm{P}_{2}$. The lowest vase life (5.28 days) was in control i.e. no pinching. In the interaction between varieties and pinching, significantly maximum vase life (7.60 days) was in $\mathrm{V}_{3} \mathrm{P}_{4}$, followed by $\mathrm{V}_{3} \mathrm{P}_{3}, \mathrm{~V}_{3} \mathrm{P}_{2}, \mathrm{~V}_{1} \mathrm{P}_{4}$ and $\mathrm{V}_{1} \mathrm{P}_{3}$. The minimum vase life (4.17 days) was observed in $\mathrm{V}_{2} \mathrm{P}_{1}$ (No pinching in Pusa Arpita variety). The vase life and keeping quality of different marigold varieties may be related to genetic makeup of that particular variety and growing environment. It could be also differed due to varied moisture content in the flowers. The variation in the vase life among different marigold varieties was earlier reported by Khanvilkar et al. (2003) [3] and Patokar et al, (2018) ${ }^{[7]}$. The significant increase in vase life of flowers may be due to the effect of pinching that helped in improving the lusture and keeping quality of flower. The pinching accelerates most of the physiological attributes, which results in increased cell division and cell elongation. The cell enlargement occurs as a result of plasticity of cell wall. This reduces the wall pressure around the cell wall and turgor pressure caused by osmotic forces in the vascular sap which lead to entry of water into the cell resulting in cell enlargement and thereby enhancing the vase life of flowers. The similar findings were earlier reported by Rathore (2007) [8].

From the present investigation it could be inferred that marigold hybrid Yellow 09 can be successfully grown with double pinching which proved to be the superior combination for good quality flowers.

Table 1: Influence of pinching in different varieties on flower diameter

\begin{tabular}{|c|c|c|c|c|}
\hline \multirow{2}{*}{ Treatment } & \multicolumn{4}{|c|}{ Diameter of flower (cm) } \\
\cline { 2 - 5 } & $\mathbf{V}_{\mathbf{1}}$ (Pusa Basanti Gainda) & $\mathbf{V}_{\mathbf{2}}$ (Pusa Arpita) & $\mathbf{V}_{\mathbf{3}}$ (Yellow 09) & Mean \\
\hline $\mathrm{P}_{1}$ (Control) & 4.12 & 3.17 & 5.54 & 4.27 \\
\hline $\mathrm{P}_{2}$ (Pinching 3 weeks after transplanting) & 4.92 & 4.35 & 5.91 & 5.17 \\
\hline $\mathrm{P}_{3}$ (Pinching 5 weeks after transplanting) & 5.19 & 4.67 & 6.57 & 5.48 \\
\hline $\mathrm{P}_{4}$ (Double Pinching) & 4.76 & 4.21 & 5.73 & 4.90 \\
\hline \multicolumn{2}{|c}{} & $\sim 2195 \sim$
\end{tabular}




\begin{tabular}{|c|c|c|c|}
\hline Mean & 4.75 & 4.10 & 5.94 \\
\hline S.Em. $\pm(\mathrm{V})$ & & 0.03 & 4.96 \\
\hline C.D. at 5\% & & 0.09 \\
\hline S.Em. (P) & & 0.04 \\
\hline C.D. at 5\% & & 0.12 \\
\hline S.Em. \pm (VXP) & \multicolumn{3}{|c|}{0.12} \\
\hline C.D. at 5\% & NS \\
\hline
\end{tabular}

Table 2: Influence of pinching on weight of flower in different varieties of marigold.

\begin{tabular}{|c|c|c|c|c|c|c|c|c|}
\hline \multirow{2}{*}{ Treatment } & \multicolumn{4}{|c|}{ Fresh weight of flower (g) } & \multicolumn{4}{|c|}{ Dry weight of flower (g) } \\
\hline & $\mathbf{V}_{1}$ & $\mathbf{V}_{2}$ & $\mathbf{V}_{3}$ & Mean & $V_{1}$ & $\mathbf{V}_{2}$ & $\mathbf{V}_{3}$ & Mean \\
\hline $\mathrm{P}_{1}$ & 5.02 & 3.37 & 6.53 & 4.98 & 1.03 & 0.98 & 1.55 & 1.19 \\
\hline $\mathrm{P}_{2}$ & 5.55 & 4.38 & 6.90 & 5.61 & 1.66 & 1.33 & 1.76 & 1.58 \\
\hline $\mathrm{P}_{3}$ & 5.86 & 4.67 & 7.54 & 6.02 & 1.88 & 1.62 & 1.98 & 1.83 \\
\hline $\mathrm{P}_{4}$ & 5.44 & 4.20 & 6.68 & 5.44 & 1.40 & 1.04 & 1.61 & 1.35 \\
\hline Mean & 5.47 & 4.16 & 6.91 & 5.51 & 1.49 & 1.24 & 1.73 & 1.49 \\
\hline S.Em. $\pm(V)$ & \multicolumn{4}{|c|}{0.015} & \multicolumn{4}{|c|}{0.003} \\
\hline C.D. at $5 \%$ & \multicolumn{4}{|c|}{0.0446} & \multicolumn{4}{|c|}{0.008} \\
\hline S.Em. $\pm(P)$ & \multicolumn{4}{|c|}{0.020} & \multicolumn{4}{|c|}{0.004} \\
\hline C.D. at $5 \%$ & \multicolumn{4}{|c|}{0.059} & \multicolumn{4}{|c|}{0.011} \\
\hline S.Em. $\pm(V X P)$ & \multicolumn{4}{|c|}{0.061} & \multicolumn{4}{|c|}{0.011} \\
\hline C.D. at $5 \%$ & \multicolumn{4}{|c|}{0.178} & \multicolumn{4}{|c|}{0.033} \\
\hline
\end{tabular}

Table 3: Influence of pinching on vase life of the flower in different varieties

\begin{tabular}{|c|c|c|c|c|}
\hline \multirow{2}{*}{ Treatment } & \multicolumn{4}{|c|}{ Vase life of flower (Days) } \\
\hline & $\mathrm{V}_{1}$ (Pusa Basanti Gainda) & $\mathrm{V}_{2}$ (Pusa Arpita) & $V_{3}($ Yellow 09) & Mean \\
\hline $\mathrm{P}_{1}$ (Control) & 5.33 & 4.17 & 6.35 & 5.28 \\
\hline $\mathrm{P}_{2}$ (Pinching 3 weeks after transplanting) & 6.23 & 4.60 & 6.81 & 5.88 \\
\hline $\mathrm{P}_{3}$ (Pinching 5 weeks after transplanting) & 7.10 & 4.85 & 7.34 & 6.43 \\
\hline $\mathrm{P}_{4}$ (Double Pinching) & 7.25 & 5.21 & 7.60 & 6.69 \\
\hline Mean & 6.48 & 4.71 & 7.02 & 6.07 \\
\hline S.Em. $\pm(V)$ & \multicolumn{4}{|c|}{0.010} \\
\hline C.D. at $5 \%$ & \multicolumn{4}{|c|}{0.028} \\
\hline S.Em. $\pm(P)$ & \multicolumn{4}{|c|}{0.013} \\
\hline C.D. at $5 \%$ & \multicolumn{4}{|c|}{0.037} \\
\hline S.Em. $\pm(V X P)$ & \multicolumn{4}{|c|}{0.038} \\
\hline C.D. at $5 \%$ & \multicolumn{4}{|c|}{0.112} \\
\hline
\end{tabular}

\section{References}

1. Asif Khan, Muhammad WA, Safi U, Atta U, Siyad A. Effect of Pinching on Growth and Flower Production of Marigold. Int J Environ Sci Nat Res. 2018; 15(1):555903.

2. Deepa VP, Patil VS, Venugopal CK, Biradar MS, Shridhar K. Study on the growth and yield attributes of marigold (Tagetes spp.) hybrids under Dharwad condition. Hort Flora Res. Spectrum. 2016; 5(1):43-47.

3. Khanvilkar ML, Kokate KD, Mahalle SS. Performance of African Marigold (Tagetes erecta) in North Kokan Coastal zone of Maharashtra. J. Maha. Agric. 2003; 28(3):333-334.

4. Mohanty CR, Mohanty A, Parhi R. Effect of planting dates on seed traits in African marigold cv. Sirakole. Agril. Science digest. 2015; 35(4):285-289.

5. Narsude PB, Kadam AS, Patil VK. Studies on the growth and quality attributes of African marigold (Tagetes erecta L.) genotypes under Marathwada condition. Asian. J. Hort. 2010; 5(2):407-410.

6. Panse VG, Sukhatme PV. Statistical methods for Agricultural workers. Indian Council of Agircultural research, New Delhi, 1995.

7. Patokar MJ, Gajbhiye RP, Patil Siddhi, Bhute PN. Yield and Quality of African marigold as Influenced by Different Varieties under Vidarbha Conditions. Int. J. Curr. Microbiol. App. Sci Special Issue. 2018; 6:14931498.
8. Rathore HS. Effect of different plant spacing and pinching on growth, yield and flower quality of marigold (Tagetes erecta Linn.). M.Sc. (Ag) Thesis Submitted to Indira Gandhi Krishi Vishwavidyalaya, Raipur (C.G.), 2007.

9. Singh D, Singh AK. Characterization of African marigold (Tagetes erecta Linn.). J. Orna. Hort. 2006; 9(1):40-42. 